UDC 621.539 .4

O.G. Velychko ${ }^{a}$, T. Liu ${ }^{a}$, S.O. Abramov ${ }^{a}$, I.V. Marchuk ${ }^{b}$, V.S. Gryshin ${ }^{a}$

\title{
TECHNOLOGICAL FEATURES OF THE PREPARATION OF CLUSTER THERMAL BARRIER COATINGS ON COPPER SURFACES OF THE CONVERTER LANCE TIPS
}

\author{
a National Metallurgical Academy of Ukraine, Dnipro, Ukraine \\ ${ }^{\mathrm{b}}$ Lutsk National Technical University, Lutsk, Ukraine
}

\begin{abstract}
The converter lance tips functioning at high external temperatures are damaged in a corrosive environment due to thermal fatigue, hot corrosion, creep, embrittlement and the synergistic influence of all these factors. Premature erosion of the blowing nozzles edges affects the blowing mode. To avoid this effect, certain reliability margins are provided at the stage of the tips design. However, despite this, during the operation of the tips, their premature destruction occurs due to the factors that are difficult to take into account in the initial calculations. The aim of the present work is to solve an important task of increasing the life cycle of the converter lance tips by creating technological methods that allow adjusting the physical-mechanical properties of the surface layer of the outer surface of copper converter lance tips. The developed methods were used for experimental investigations of the energy-power parameters of abrasive blasting treatment process, residual stresses in the coatings and the influence of electrolytic-plasma processing upon a cluster coating obtained by electrospark doping followed by the preparation of an electrolyticplasma thermal barrier coating. A comprehensive, economically viable and environmentally friendly technological process for the fabrication of the electrolytic-plasma thermal barrier coating on the converter lance tips has been developed and substantiated. This process allows increasing significantly their resistance and thereby improves the steelmaking parameters.
\end{abstract}

Keywords: lance, backing preparation, electrolytic-plasma processing, protective coating, roughness.

DOI: $10.32434 / 0321-4095-2020-130-3-53-58$

\section{Introduction}

The experience in operation of oxygen lance tips of various designs, accident statistics, and experimental studies showed that the destruction of the tip begins commonly from the surface. The surface quality of the lance copper tip is one of the main factors determining its thermal and fatigue strength as well as plastic deformation or creep deformation that lead to erosion of nozzle edges (Fig. 1), destruction of welds, etc.

The creep curve has various stages, which coincide with the typical loading conditions of the lance tip during blowing at four intervals (Fig. 2).

When the blowing of the molten bath with oxygen starts, the lances are immersed in the converter and the tip undergo instant deformation resulted in the initial creep. At this stage, the creep rate gradually decreases reaching a constant (i.e. steady-state) value of secondary creep. At the third stage of blowing, the creep rate begins to increase, which leads to the beginning of the surface layer destruction. At the fourth stage (lifting the lance to its upper position), the tip undergoes instant

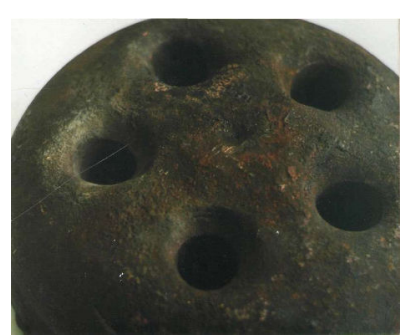

a

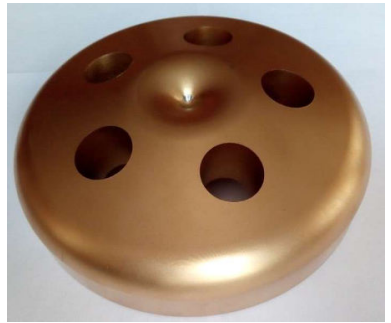

b
Fig. 1. The copper crown of the converter lance tip: $a-$ the outer surface before operation; $b-$ the outer surface after operation 


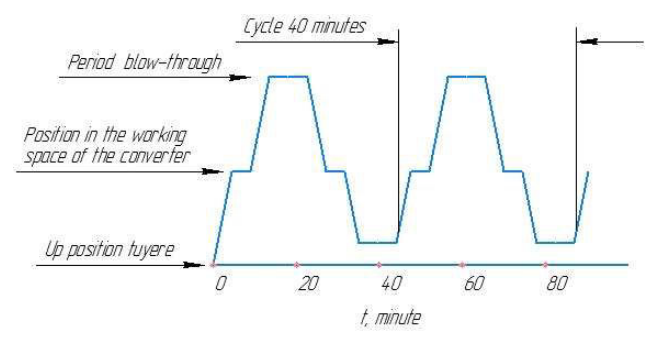

Fig. 2. Schematic blowing cycle of the converter bath

deformation due to sudden cooling. In general, creep deformation is a function of the creep stress, time and temperature.

Besides, it is known that the smaller the surface roughness, the higher the fatigue strength of the parts [1]. Roughnesses of the surface are stress concentrators; they are one of the reasons for reducing fatigue strength.

To prevent the erosion of nozzle edges of copper converter lance tips, in addition to increasing the cooling conditions of the internal surfaces, the external surface is covered with refractory metals, for example, molybdenum, tungsten, etc. [2-4]. However, the application of a continuous coating of refractory metals does not provide high resistance. This is caused by the occurrence of internal stresses in the coating and crown material. In addition, during blowing, the copper crown heating and cooling leads to disruption of coating continuity and cracks in copper due to different coefficient of volumetric expansion. An effective way to improve the quality of the coating is to strengthen its adhesion to the base material, which largely depends on the backing preparation.

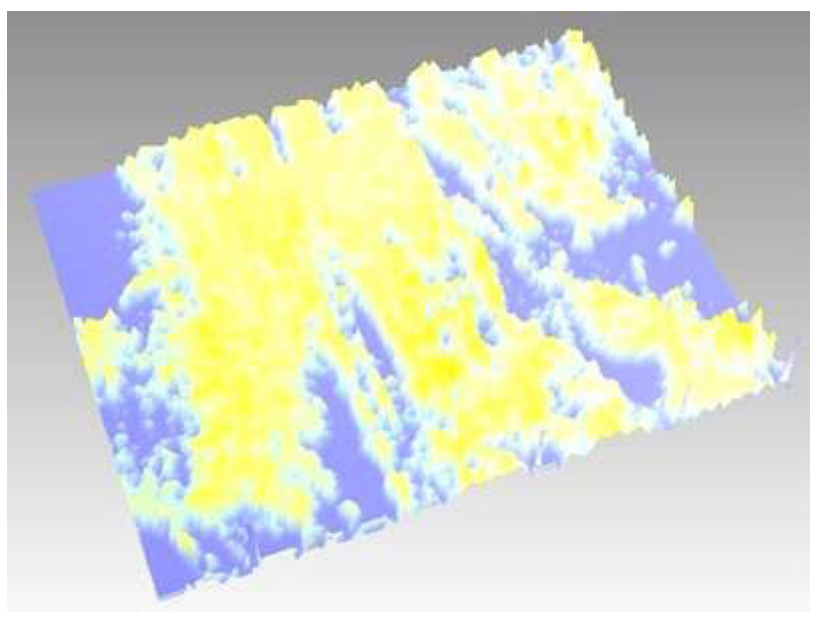

a

Fig. 3. The surface of the copper sample after machining and before activation: $a-3 D$ surface topography; $b-$ surface
macrosection (relief dimensions are given in $\mu \mathrm{m}$ )

Fig. 3. The surface of the copper sample after machining and before activation: a $-3 \mathrm{D}$
macrosection (relief dimensions are given in $\mu \mathrm{m}$ )
The aim of the present work is to solve an important task of increasing the life cycle of the converter lance tips by creating technological methods that allow adjusting the physical-mechanical properties of the surface layer of the outer surface of copper converter lance tips.

\section{Experimental, results and discussion}

To determine the rational method of backing preparation for the coating, an analysis of the tip surface quality treated by traditional technology was made (Fig. 3).

The study of the effects of backing preparation on the quality of coatings placed on a noncontinuous copper tip surface formed by second-order curves showed that the most acceptable is an abrasive blasting method, which allows increasing the adhesion of the backing-coating system and optimizing the roughness and structure of the outer surface of the tip [4-6].

Spherical granules of high impact styrene copolymer were used as abrasive material (Fig. 4) [7].

The interaction of the styrene copolymer granules with the copper surface of the tip leads to the formation of an arbitrary microrelief and removal of oxide films, which increases the adhesion of the applied electrospark coating with the formed backing.

A large number of factors affect the process of abrasive blasting. One of the main ones is the resulting force acting on each granule. It is evident that the resulting force is a sum of the pressure-force of the blast, the force arising from the action of the force moment, which orients the granules in the abrasive stream, the inertial and centrifugal forces that occur

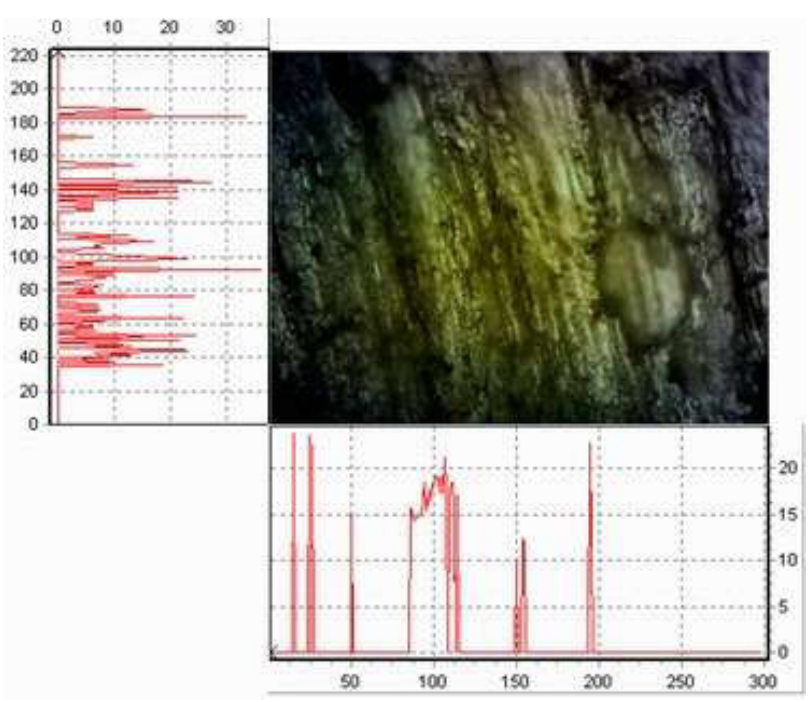




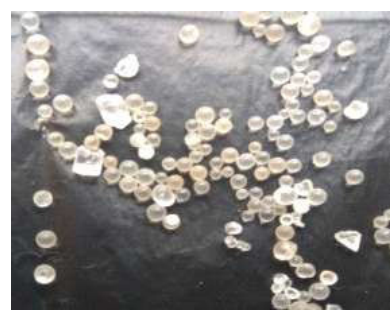

a

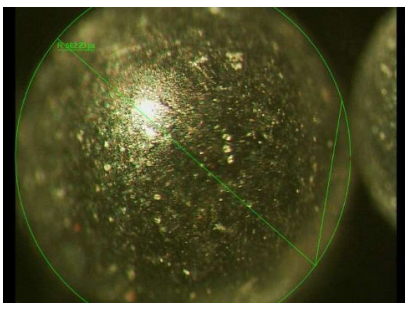

b

Fig. 4. Styrene copolymer granules: a - general view; $\mathrm{b}$ - a single granule $\left(\mathrm{D}_{\mathrm{av}}=1500 \mu \mathrm{m}\right)$

during accelerated motion of the granule, the weight force, the common force in contact of the granule with the surrounding granules and the frictional force upon the contact of granules with the treated surface during elastoplastic deformation.

The study was carried out under the following assumptions: the granules of the impact-resistant styrene copolymer have the same spherical shape (Fig. 4,a); granules are rigid; and the ratio of the real granules sizes to the size of tip surface being processed allows us to consider the working gap as flat.

One of the requirements for the preparation of the surface for coating is to reduce the surface roughness, the change of which can be defined as:

$$
\mathrm{R}_{\mathrm{a}_{\mathrm{i}}}(\mathrm{Z}, \mathrm{V})=\sum_{\mathrm{j}=1}^{\mathrm{N}} \mathrm{r}(\mathrm{Z}, \mathrm{V}) \rightarrow \min
$$

where $\mathrm{N}$ is the number of individual events of contact interaction on the elementary site; $r$ is the size of the hole after a single event of contact interaction; $\mathrm{Z}$ is the grain fineness of the abrasive particles and $\mathrm{V}$ is the speed of the abrasive flow.

In this case, the removal of material is taken as a limitation:

$$
\mathrm{G}_{\mathrm{i}}(\mathrm{Z}, \mathrm{V}) \rightarrow \min
$$

The roughness values of the copper lance tip surface activated for coating by the abrasive blasting method were determined by means of the contactless 3-D interference profilograph «Micron-alpha». This profilograph allows registering the surfaces topography by processing a sequence of interference data (pictures) recorded by a digital camera when the reference (reference standard) mirror is shifted. The results of the samples surface research after abrasive blasting treatment are shown in Fig. 5 .

The analysis of the experimental data showed that the abrasive blasting surface activation quite abruptly changes the parameters of the formed microprofile and thereby can reduce creep and

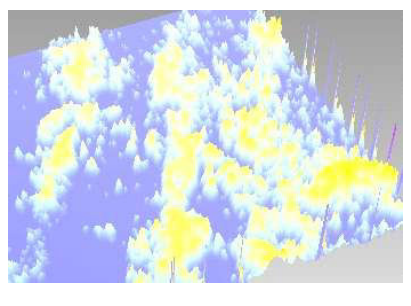

a

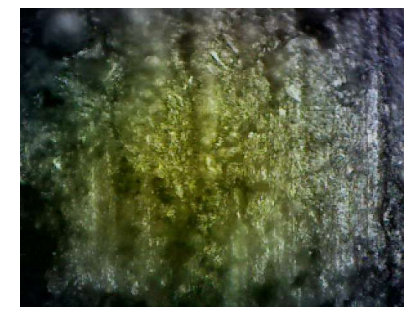

b
Fig. 5. The surface of the copper sample after abrasive blasting treatment: a - 3-D surface topography; $\mathrm{b}-$ surface macrosection

increase fatigue strength.

One of the promising directions for an increase in the wear resistance of oxygen lance tips is the use of protective coatings, in particular, electrospark doping (ESD) [8]. The main advantages of this technology are as follows: the possibility of application of various conductive materials as a substrate, high strength and adhesion of the hardened layer with the main material, local coating without noticeable deformation of parts and the absence of heating of the entire body of the lance tip.

However, the use of electrospark doping for hardening the surface layers of parts of metallurgical equipment is constrained by a number of factors, such as relatively low productivity of the process and small thickness and continuity of the coating.

The quality of the surface that has been treated with electrospark doping is determined by the geometric dimensions of the holes, the degree of their mutual overlapping and the size of the resulting sags. As a result of the discharge, metal from the treated surface is splattered and irregularities (sags) appear on the holes and distort their shape. Figure 6 , a presents single holes obtained after subjecting a copper sample to an electric discharge with a chromium-nickel alloy electrode. Figure 6, b shows an image of the copper sample with a hole (cluster) doped with nickel.

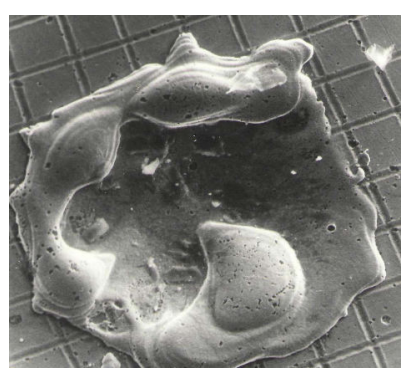

a

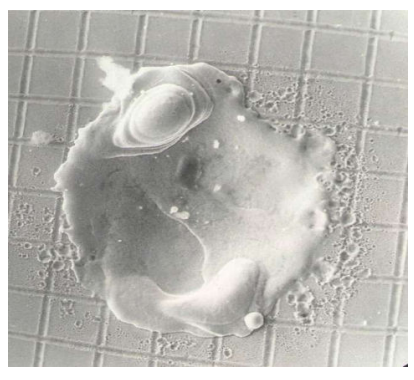

b
Fig. 6. Images of single holes (clusters) on the surface of a copper sample doped with a chromium-nickel alloy electrode $(\times 200)$ 
It is known [8] that deep structural transformations occur in the surface layer during the ESD process which change its physical-mechanical properties, in particular, residual stresses. So, in the ESD treatment, they are caused by non-stationary processes of the heating and cooling of a material in the zone of a pulsed discharge. Residual stresses in coatings have a significant effect on the working properties of hardened parts. The nature of the distribution of residual stresses during ESA is affected by the anode material, time and coating technology. At the same time, it can provide a coating continuity of up to $70 \%$ of the total area, therefore, it relates to discrete structure coatings [9].

To increase the protective corrosion properties of coatings and outer copper surfaces of oxygen lance tips, it is necessary to use technologies for continuous coating.

Nickel and chromium-based alloys belong to materials that have good creep resistance at high temperature, low ductility and a good corrosion resistance at high temperature. As a rule, they are surfaced by electrochemical deposition processes in electrolytes. However, such electrodeposits have inherent disadvantages: cracking and peeling at low mechanical cyclic loads (Fig. 7).
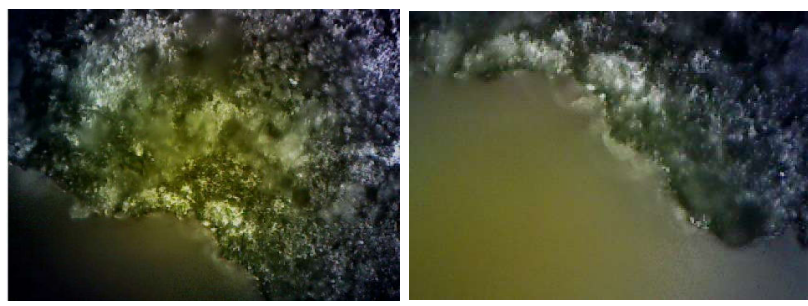

Fig. 7. Topography of the surface of a sample with defects in a continuous coating

A promising method that meets modern requirements is an electrolytic-plasma coating, which can significantly increase the life cycle of the converter lance tips.

The processing time, the concentration of electrolyte and the quality of the backing surface for coating (type of microrelief and roughness) are parameters that characterize the process of electrolytic-plasma coating. The backing was prepared by electrolytic-plasma processing after electrospark doping [10-13].

An aqueous electrolyte containing ammonium sulfate $(1 \%)$ was used in the process,. For the electrolytic-plasma coating of nickel, a $30 \%$ aqueous solution of nickel sulfate with $\mathrm{pH}$ of $\sim 3.8$ and conductivity of $44 \mathrm{~m}^{-1} \mathrm{~cm}^{-1}$ at the temperature of $70^{\circ} \mathrm{C}$ was applied.
The main and indispensable condition for overgrowing holes (i.e. clusters) formed by electrospark doping in the electrolytic-plasma coating is a sufficient thickness of the applied layer to obtain a uniform protective coating (Fig. 8).

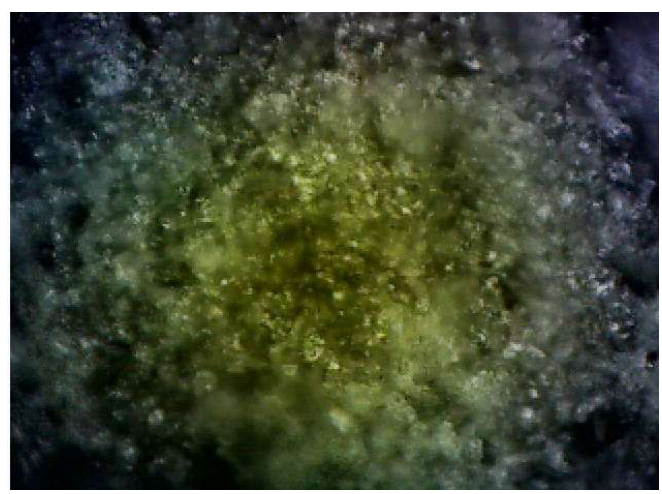

Fig. 8 Copper sample with cluster thermal barrier coating

\section{Conclusions}

The process of the preparation of cluster thermal barrier coatings on oxygen lance tips was investigated. Industrial tests were carried out on a 250-ton convertor at the Eco-Steel metallurgical plant in Eisenhuttenstad (Germany). The six-nozzle oxygen lance tip with a thermal barrier coating showed resistance that is 2 times higher than the resistance of the standard tips used in the converter shop of the plant. The testing of five-nozzle tip using the 60-ton converter of the metallurgical plant in the city of Dnipro (Ukraine) showed an increase in the resistance by 3.5 times in comparison with the resistance of tips manufactured at that plant.

The feasibility of the integrated process for the fabrication of cluster thermal barrier coatings on the outer surfaces of copper oxygen lance tips was substantiated. The backing was treated with spherical granules of high-impact styrene copolymer followed by the discrete electrospark doping with alloys based on the protective coating material.

A comprehensive, economically viable and environmentally friendly technological process of the preparation of electrolytic-plasma thermal barrier coating on the converter lance tips has been developed and investigated. It allows significantly increasing their resistance and thereby improving the steelmaking parameters. 


\section{REFERENCES}

1. Suslov A.G. Inzheneriya poverkhnosti detalei. M.: Mashinostroenie, 2008. - $320 \mathrm{p}$.

2. Sushchenko A.V. Sovershenstvovanie i optimizatsiya dut'yevykh rezhimov i ustroistv kislorodnykh konverterov // Newsl. Priazovsky Technol. Univ. - 2009. - No. 19. - P.36-41.

3. Enhancing the efficiency of water cooling of oxygen blowing lance tip / Velychko O.G., T Liu, Abramov S.O., Gryshin V.S. // Theor. Pract. Metall. - 2018. - No. 1-2(11213). - P.7-13.

4. Khanna Y.K., Mohanty S.S. Improvement in blowing parameters by modification in lance tip design // AISTech. Iron and Steel Technol. Conf. Proceed. - Indianapolis, United States, 2014. - P.1323-1330.

5. Effect of carbide interlayers on the microstructure and properties of graphene-nanoplatelet-reinforced copper matrix composites / Si X., Li M., Chen F., Eklund P., Xue J., Huang F., Du S., Huang Q. // Mater. Sci. Eng. A. - 2017. - Vol.708. P.311-318.

6. $\mathrm{Cu}-\mathrm{Mn}$-Co oxides as protective materials in SOFC technology: the effect of chemical composition on mechanochemical synthesis, sintering behaviour, thermal expansion and electrical conductivity / Masi A., Bellusci M., McPhail S.J., Padella F., Reale P., Hong J.-E., SteinbergerWilckens R., Carlini M. // J. Eur. Ceram. Soc. - 2017. - Vol.37. - No. 2. - P.661-669.

7. Texturing the lamellae of the collector of electrical machines / Abramov S., Serdiuk T., Synytsina Y., Gryshin V., Babiak M. // Proceed. «IEEE 2nd Ukr. Conf. Electric. Comp. Eng. UKRCON-2019». - Ukraine, Lviv, 2019. - P.634-640.

8. Nanostructuring a steel surface by electrospark treatment with new electrode materials based on tungsten carbide / Nikolenko S.V., Kuz'menko A.P., Timakov D.I., Abakymov P.V. // Surf. Eng. Appl. Electrochem. - 2011. - Vol.47. - P.217-224.

9. Influence of electrospark discharge parameters on roughness and microabrasive wear of steel 45 surface after ESA by TiC-based electrodes / Nikolenko S.V., Verkhoturov A.D., Syui N.A., Kuz'michev E.N. // Surf. Eng. Appl. Electrochem. 2016. - Vol.52. - P.342-349.

10. Soroka O.V. Vybir parametriv dyskretnomodyfikovanykh znosostiikykh poverkhon' [Choice of the parameters of discretely modified wear-resistant surfaces]. Visnyk Natsional'nogo Tekhnichnogo Universytetu Ukrayiny «Kyivs'kyi Politekhnichnyi Instytut», Priladobuduvannya. - 2007. No. 33. - P.119-126.
11. Smith A.J. Surface modification of iron and aluminum by electrolytic plasma processing. - University of Texas at Arlington, 2014. - $144 \mathrm{p}$.

12. Zhurerova L., Rakhadilov B., Tabieva Y. Plasmaelectrolytic nitriding of $0.3 \mathrm{Cr}-1 \mathrm{Mn}-1 \mathrm{Si}-\mathrm{Fe}$ construction steel // METAL 2019 - 28th Int. Conf. Metal. Mater., Conf. Proceed. - Czech Republic, 2019. - P.1174-1179.

13. Nehrub S., Volodko E. Kombinirovannyi metod naneseniya pokrytii posredstvom elektrolitno-plazmennoi tekhnologii // Bulletin of NTU «KhPI». Ser. MechanicalTechnological Systems and Complexes. - 2016. - No. 7(1179). - P.13-19.

Received 26.02.2020

\section{ТЕХНОЛОГІЧНІ ОСОБЛИВОСТІ НАНЕСЕННЯ КЛАСТЕРНИХ ЗАХИСНИХ ПОКРИТТІВ НА МІДНІ ПОВЕРХНІ НАКОНЕЧНИКІВ КОНВЕРТЕРНИХ ФУРМ}

\section{О.Г. Величко, Т.І. Лю, С.О. Абрамов, І.В. Марчук, В.С. Гришин}

Наконечники конвертерних фурм, що експлуатуються при високих зовнішніх температурах, у корозійному середовищі зазнають пошкодження унаслідок термічної утомленості, гарячої корозії, повзучості, окрихковання і сінергетичного впливу перерахованих факторів. Для виключення дочасного розпалу країв продувальних сопел, які значно впливають на режсм продування, на етапі проектування виробники наконечників конвертерних фурм впроваджують визначені запаси надійності. Однак, не дивлячись на це, у процесі експлуатації наконечників відбуваються передчасні їх руйнування, унаслідок впливу чинників, які складно врахувати в початкових розрахунках. Метою даної роботи є вирішення важливої задачі підвищення жсттєвого циклу деталей і вузлів наконечників дуттєвих пристроїв металургійних агрегатів шляхом створення технологічних методів, які формують фізико-механічні характеристи$к и$ поверхневого шару зовнішньої поверхні мідних наконечників кисневих фурм. Розроблені методи використано для експериментального дослідження енергосилових параметрів процесу струменево-абразивного оброблення, залишкових напружень у покриттях, та впливу пароплазмового полірування і нанесення кластерного покриття електроіскровим легуванням з подальшим нанесенням пароплазмового захисного покриття. Обтрунтовано доцільність створення комплексного технологічного процесу нанесення кластерних захисних покриттів на зовнішні поверхні мідних наконечників кисневих фурм.

Ключові слова: фурма, підготовка підкладки, пароплазмове полірування, захисне покриття, шорсткість. 


\section{TECHNOLOGICAL FEATURES OF THE PREPARATION OF CLUSTER THERMAL BARRIER COATINGS ON COPPER SURFACES OF THE CONVERTER LANCE TIPS}

O.G. Velychko ${ }^{a}$, T. Liu ${ }^{a}$, S.O. Abramov ${ }^{a, ~ *, ~ I . V . ~ M a r c h u k ~}{ }^{\text {, }}$, V.S. Gryshin ${ }^{a}$

a National Metallurgical Academy of Ukraine, Dnipro, Ukraine

${ }^{b}$ Lutsk National Technical University, Lutsk, Ukraine

* e-mail: abramovs706@gmail.com

The converter lance tips functioning at high external temperatures are damaged in a corrosive environment due to thermal fatigue, hot corrosion, creep, embrittlement and the synergistic influence of all these factors. Premature erosion of the blowing nozzles edges affects the blowing mode. To avoid this effect, certain reliability margins are provided at the stage of the tips design. However, despite this, during the operation of the tips, their premature destruction occurs due to the factors that are difficult to take into account in the initial calculations. The aim of the present work is to solve an important task of increasing the life cycle of the converter lance tips by creating technological methods that allow adjusting the physicalmechanical properties of the surface layer of the outer surface of copper converter lance tips. The developed methods were used for experimental investigations of the energy-power parameters of abrasive blasting treatment process, residual stresses in the coatings and the influence of electrolytic-plasma processing upon a cluster coating obtained by electrospark doping followed by the preparation of an electrolytic-plasma thermal barrier coating. A comprehensive, economically viable and environmentally friendly technological process for the fabrication of the electrolytic-plasma thermal barrier coating on the converter lance tips has been developed and substantiated. This process allows increasing significantly their resistance and thereby improves the steelmaking parameters.

Keywords: lance; backing preparation; electrolytic-plasma processing; protective coating; roughness.

\section{REFERENCES}

1. Suslov A.G., Inzheneriya poverkhnosti detalei [Surface engineering]. Mashinostroenie Publishers, Moscow, 2008. 320 p. (in Russian).

2. Sushchenko A.V. Sovershenstvovanie i optimizatsiya dut'yevykh rezhimov i ustroistv kislorodnykh konverterov [Improvement and optimization of blow modes and devices of oxygen converters]. Newsletter of the Priazovsky Technological University, 2009, no. 19, pp. 36-41. (in Russian).

3. Velychko O.G., T Liu, Abramov S.O., Gryshin V.S. Enhancing the efficiency of water cooling of oxygen blowing lance tip. Theory and Practice of Metallurgy, 2018, no. 1-2(112-13), pp. 7-13.

4. Khanna Y.K., Mohanty S.S., Improvement in blowing parameters by modification in lance tip design. AISTech - Iron and Steel Technology Conference Proceedings, United States, Indianapolis, 2014, pp. 1323-1330.
5. Si X., Li M., Chen F., Eklund P., Xue J., Huang F., Du S., Huang Q. Effect of carbide interlayers on the microstructure and properties of graphene-nanoplatelet-reinforced copper matrix composites. Materials Science and Engineering: A, 2017, vol. 708, pp. 311-318.

6. Masi A., Bellusci M., McPhail S.J., Padella F., Reale P., Hong J.-E., Steinberger-Wilckens R., Carlini M. Cu-Mn-Co oxides as protective materials in SOFC technology: the effect of chemical composition on mechanochemical synthesis, sintering behaviour, thermal expansion and electrical conductivity. Journal of the European Ceramic Society, 2017, vol. 37, pp. 661-669.

7. Abramov S., Serdiuk T., Synytsina Y., Gryshin V., Babiak M., Texturing the lamellae of the collector of electrical machines. Conference Proceedings «IEEE 2nd Ukraine Conference on Electrical and Computer Engineering UKRCON-2019», Ukraine, Lviv, 2019, pp. 634-640.

8. Nikolenko S.V., Kuz'menko A.P., Timakov D.I., Abakymov P.V. Nanostructuring a steel surface by electrospark treatment with new electrode materials based on tungsten carbide. Surface Engineering and Applied Electrochemistry, 2011, vol. 47, pp. 217-224.

9. Nikolenko S.V., Verkhoturov A.D., Syui N.A., Kuz'michev E.N. Influence of electrospark discharge parameters on roughness and microabrasive wear of steel 45 surface after ESA by TiC-based electrodes. Surface Engineering and Applied Electrochemistry, 2016, vol. 52, pp. 342-349.

10. Soroka O.V. Vybir parametriv dyskretnomodyfikovanykh znosostiikykh poverkhon' [Choice of the parameters of discretely modified wear-resistant surfaces]. Visnyk Natsional'nogo Tekhnichnogo Universytetu Ukrayiny «Kyivs'kyi Politekhnichnyi Instytut», Priladobuduvannya, 2007, no. 33, pp. 119-126. (in Ukrainian).

11. Smith A.J., Surface modification of iron and aluminum by electrolytic plasma processing. University of Texas at Arlington Publishers, 2014. 144 p.

12. Zhurerova L., Rakhadilov B., Tabieva Y., Plasmaelectrolytic nitriding of $0.3 \mathrm{Cr}-1 \mathrm{Mn}-1 \mathrm{Si}-\mathrm{Fe}$ construction steel. METAL 2019 - 28th International Conference on Metallurgy and Materials, Conference Proceedings, Czech Republic, 2019, pp. 1174-1179.

13. Nehrub S., Volodko E. Kombinirovannyi metod naneseniya pokrytii posredstvom elektrolitno-plazmennoi tekhnologii [Combined method of coating electrolytic-plasma technology]. Bulletin of NTU «KhPI». Series: MechanicalTechnological Systems and Complexes, 2016, no. 7(1179), pp. 1319. (in Russian). 